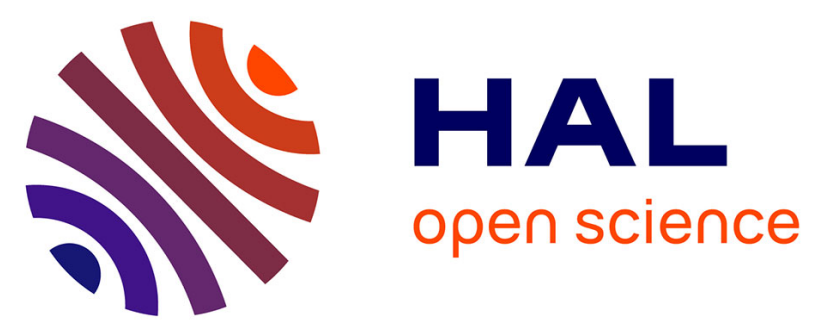

\title{
A High Power Buckypaper Biofuel Cell: Exploiting 1,10-Phenanthroline-5,6-dione with FAD-Dependent Dehydrogenase for Catalytically-Powerful Glucose Oxidation
}

Andrew J. Gross, Xiaohong Chen, Fabien Giroud, Caroline Abreu, Alan Le Goff, Michael Holzinger, Serge Cosnier

\section{To cite this version:}

Andrew J. Gross, Xiaohong Chen, Fabien Giroud, Caroline Abreu, Alan Le Goff, et al.. A High Power Buckypaper Biofuel Cell: Exploiting 1,10-Phenanthroline-5,6-dione with FAD-Dependent Dehydrogenase for Catalytically-Powerful Glucose Oxidation. ACS Catalysis, 2017, 7 (7), pp.4408 - 4416. 10.1021/acscatal.7b00738 . hal-01616374

\section{HAL Id: hal-01616374 \\ https://hal.univ-grenoble-alpes.fr/hal-01616374}

Submitted on 19 Nov 2020

HAL is a multi-disciplinary open access archive for the deposit and dissemination of scientific research documents, whether they are published or not. The documents may come from teaching and research institutions in France or abroad, or from public or private research centers.
L'archive ouverte pluridisciplinaire HAL, est destinée au dépôt et à la diffusion de documents scientifiques de niveau recherche, publiés ou non, émanant des établissements d'enseignement et de recherche français ou étrangers, des laboratoires publics ou privés. 


\title{
A High Power Buckypaper Biofuel Cell: Exploiting 1,10- 2 Phenanthroline-5,6-dione with FAD-Dependent Dehydrogenase for ${ }_{3}$ Catalytically-Powerful Glucose Oxidation
}

\author{
${ }_{4}$ Andrew. J. Gross, $\left.{ }^{*}{ }^{(}\right)$Xiaohong Chen, ${ }^{(0)}$ Fabien Giroud, Caroline Abreu, Alan Le Goff, ${ }^{\circ}$ \\ ${ }_{5}$ Michael Holzinger, ${ }^{\circledR}$ and Serge Cosnier* \\ 6 Department of Molecular Chemistry, UMR CNRS-UGA 5250, Université Grenoble Alpes, 38000 Grenoble, France \\ 7 S Supporting Information
}

\begin{abstract}
Enzymatic biofuel cells generate electrical energy from renewable sources with high selectivity and environmental benefits compared to lithium batteries and traditional fuel cells. For enzymatic fuel cells to become competitive, major improvements in electrode design are required to enhance power density, voltage output, and stability. Here we have developed a freestanding paper biofuel cell comprising redox molecule embedded multiwalled carbon nanotube papers for electrical wiring of enzymes. The drop-coat and one-pot fabrication

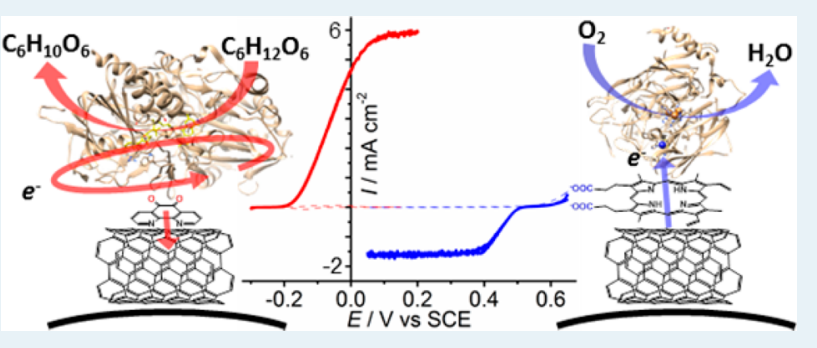
methods provide flexibility and permit easy scalability of functionalized bioelectrodes via commercially available materials. Buckypaper functionalized with 1,10-phenanthroline-5,6-dione (PLQ) as an efficient electron mediator for fungal-derived FADdependent glucose dehydrogenase (FADGDH) shows very high steady-state current densities for glucose oxidation of $I_{\max }=5.38$ $\pm 0.54 \mathrm{~mA} \mathrm{~cm}^{-2}$ at $0.15 \mathrm{~V}$ vs SCE at neutral $\mathrm{pH}$. When coupled with a bioinspired protoporphyrin IX buckypaper cathode, the resulting glucose $/ \mathrm{O}_{2}$ fuel cell delivered a power density of $0.65 \pm 0.1 \mathrm{~mW} \mathrm{~cm}^{-2}$ or $24.1 \pm 4.7 \mathrm{~mW} \mathrm{~cm}^{-3}$ at a cell voltage of $0.5 \mathrm{~V}$, limited by the cathode. Galvanostatic and current discharge experiments confirm robust short-term operational performance.

KEYWORDS: bioelectrocatalysis, biocatalyst, paper electrode, enzymatic, FAD-GDH, multicopper oxidases
\end{abstract}

25 Enzymatic biofuels (EBFCs) convert chemical energy into 26 electrical energy under mild conditions from the oxidation of 27 organic fuels such as sugars and alcohols, coupled with the 28 reduction of oxygen using redox enzymes as bioelectrocata29 lysts. ${ }^{1-3}$ Biofuel cells offer several advantages over lithium 30 batteries and traditional fuel cells, including the use of 31 renewable, low-cost, and safe fuels from ecological sources 32 and operation at neutral $\mathrm{pH}$ and ambient temperature. 33 Furthermore, EBFCs can operate as membraneless fuel cells 34 owing to the high selectivity of enzymes. Particular attention of 35 biofuel cells over the past decade has been directed toward the 36 use of EBFCs as micropower sources which harvest energy 37 from biological fluids for implantable medical devices. ${ }^{4-7}$ In 38 recent years, EBFCs have been successfully implanted in rats, ${ }^{4}$ 39 lobsters, ${ }^{5}$ and snails. ${ }^{6}$ Application of EBFCs for portable and 40 wearable devices is more feasible and has enormous potential. ${ }_{41}$ For example, epidermal and contact-lens biofuel cells which 42 harvest energy from sweat or tears using carbon nanotube 43 based electrodes have started to emerge. ${ }^{8-10}$ Lightweight 44 biofuel cells with small form factors offer the prospect of self45 powered chemical sensors with in situ detection and 46 remediation of toxic chemicals. ${ }^{11,12}$

47 Specific challenges in EBFC electrode design include the 48 development of electrodes which offer (i) stable immobilization 49 of enzymes and mediators with high loadings, (ii) efficient electron transfer between the active sites of enzymes and the 50 electrode, and (iii) fast mass transport and (iv) are lightweight 51 and easily integrated into devices. To achieve the practical 52 application of biofuel cells, a rapidly emerging approach is to 53 use flavin adenine dinucleotide-dependent glucose dehydrogen- 54 ase (FADGDH) for catalytic oxidation of glucose at the anode. 55 The FADGDH enzyme offers major advantages for biofuel cells 56 compared to other popular FAD-dependent enzymes such as 57 the gold standard glucose oxidase (GOx) ${ }^{13,14}$ Unlike GOx, 58 FADGDH is oxygen insensitive, which prevents consumption 59 of valuable oxygen at the anode. In situ production of hydrogen 60 peroxide, which can be toxic to single compartment fuel cells, is 61 also avoided. ${ }^{14}$ However, the commercially available fungal 62 FADGDH does not have the cytochrome-complex subunit for 63 direct electron transfer (DET) with electrodes. ${ }^{15}$ As such, the 64 fungal FADGDH requires an artificial electron transfer 65 mediator, which can result in kinetic and thermodynamic 66 losses compared to DET. ${ }^{16}$ The identification of high 67 performance mediators is vital for fungal FADGDH for both 68 biofuel cell and sensor applications. Few systems for mediated 69 electron transfer with FADGDH have been investigated and are 70 mainly based on osmium, ${ }^{13,17-19}$ ruthenium, ${ }^{20}$ and ferro- 71

Received: March 7, 2017

Revised: $\quad$ May 15, 2017

Published: May 22, 2017 
72 cene $^{14,21}$ redox complexes and polymers. These mediators have 73 high redox potentials and slow mediator exchange due to 74 structural rigidity and require complicated synthesis from toxic 75 precursors. Compared to metal-based mediators, small organic 76 mediators with fast mediator exchange are attractive. For 77 example, 1,2 and 1,4 naphthoquinones ${ }^{22,23}$ and phenothia78 zines $^{24,25}$ are commonly exploited and give high catalytic 79 currents at attractively low formal redox potentials.

80 Carbon nanotubes (CNTs) offer great advantages for 81 bioelectrodes and are typically deposited onto an electrode 82 support to give a large surface area with good stability and 83 conductivity. ${ }^{26}$ CNT-supported electrodes tend to be heavy, 84 bulky, and not easily miniaturizable. ${ }^{27,28}$ Free-standing bucky85 paper electrodes prepared by vacuum filtration of CNT 86 suspensions on the other hand are thin and lightweight and 87 offer the possibility to immobilize catalysis-promoting aromatic 88 molecules by $\pi$-stacking interactions. ${ }^{29-32}$ However, such paper 89 electrodes are often fragile with limited conductivity and slow 90 electron transfer kinetics compared to conventional bulk 91 electrodes such as glassy carbon (GC). Further improvements 92 in fabrication methods are required toward CNT paper 93 electrodes with excellent homogeneity, reproducibility, and 94 electrochemical properties.

95 In this study, we report the preparation of new redox 96 molecule embedded buckypapers for bioelectrocatalysis using 97 four different types of commercially available redox molecules. 98 The focus of the study is the development of high performance 99 catalytic buckypaper bioelectrodes for enzyme wiring without 100 the use of a supporting substrate or polymer scaffold. The use 101 of 1,10-phenanthroline-5,6-dione (PLQ) as a small electron 102 mediator for the fungus-derived FADGDH is explored, and the 103 resulting buckypaper anode integrated into a fully freestanding 104 paper glucose $/ \mathrm{O}_{2}$ biofuel cell with a protoporphyrin bucky105 paper cathode. Notably, our approach here uses PLQ as a small 106 organic mediator and nanotube binder and therefore avoids 107 polymer and metal complex synthesis. This is in contrast to the 108 structurally and electronically different $\mathrm{Ru}$ polymer mediator 109 with PLQ ligands reported previously. ${ }^{20}$

\section{EXPERIMENTAL SECTION}

111 Materials and Apparatus. Monosodium phosphate 112 monohydrate $\left(\mathrm{NaH}_{2} \mathrm{PO}_{4}, \geq 98 \%\right)$, disodium hydrogen phos113 phate heptahydrate $\left(\mathrm{Na}_{2} \mathrm{HPO}_{4}, 98-102 \%\right), N, N$-dimethylfor114 mamide (DMF, 99.9\%), potassium ferricyanide, 1,10-phenan115 throline-5,6-dione (PLQ 97\%), protoporphyrin IX (PP, $\geq 95 \%$, 116 ferriprotoporphyrin IX (FePP, $\geq 98.0 \%$ ), 1,4 naphthoquinone 117 (NQ, 97\%), potassium chloride (KCl, 99\%), D-(+)-glucose $118(\geq 99.5 \%)$, sodium citrate $(>99 \%)$, sodium chloride $(\mathrm{NaCl}$, $11999.8 \%)$, copper chloride $\left(\mathrm{CuCl}_{2}, 97 \%\right)$, hydrogen peroxide $120\left(\mathrm{H}_{2} \mathrm{O}_{2}, 30\right.$ wt $\%$ in $\left.\mathrm{H}_{2} \mathrm{O}\right)$, ethylenediaminetetraacetic acid 121 (EDTA, 99\%), and sulfuric acid (95-98\%) were purchased 122 from Sigma-Aldrich and used as received. Bilirubin oxidase 123 (BOD, $1.2 \mathrm{U} \mathrm{mg}^{-1}$ ) from Myrothecium sp. and flavin adenine 124 dinucleotide-dependent glucose dehydrogenase (FADGDH, $1251150 \mathrm{U} \mathrm{mg}^{-1}$ solid) from Aspergillus sp. were purchased from 126 Amano (Japan) and Sekisui Diagnostics (UK), respectively, and 127 used as received. Enzymes were stored at $-20{ }^{\circ} \mathrm{C}$. Distilled 128 water was obtained by water purification to a resistivity of 15 $129 \mathrm{M} \Omega \mathrm{cm}$ using a Millipore Ultrapure system. Commercial grade 130 multiwalled carbon nanotubes (MWCNTs, $\varnothing=9.5 \mathrm{~nm}, 1.5 \mu \mathrm{m}$ 131 length, $\geq 95 \%$ purity) were obtained from Nanocyl and used as 132 received without purification. High purity oxygen and argon were obtained from Messer. Glucose solutions were left to 133 mutarotate overnight to $\beta$-D-glucose prior to use.

Preparation of Unmodified MWCNT Buckypaper and 135 Redox-Embedded MWCNT Buckypaper Electrodes by 136 Drop-Coat Method. First, a $1 \mathrm{mg} \mathrm{mL}^{-1}$ MWCNT suspension 137 was prepared by the addition of $150 \mathrm{mg}$ of nonfunctionalized 138 MWCNTs into $150 \mathrm{~mL}$ of DMF. The dispersion was then 139 sonicated for $30 \mathrm{~min}$ prior to use. After vigorous shaking for 1140 min, $66 \mathrm{~mL}$ of the suspension was filtered through a Millipore 141 PTFE filter (JHWP, $0.45 \mu \mathrm{m}$ pore size, $\varnothing=46 \mathrm{~mm}$ ) using a 142 vacuum pump, washed with distilled water, and left for $1 \mathrm{~h} .143$ After filtration, the resulting unmodified buckypaper with $\varnothing=144$ $35 \mathrm{~mm}$ was left to dry at room temperature. The buckypaper 145 was obtained after its careful removal from the filter paper, then 146 cut into individual electrodes with $\varnothing=10 \mathrm{~mm}$ (geometric 147 surface area of $0.785 \mathrm{~cm}^{-2}$ ) using a metal cutter. To obtain 148 functionalized MWCNT buckypaper electrodes, $150 \mu \mathrm{L}$ of 0.6149 mmol L ${ }^{-1}$ or $10 \mathrm{mmol} \mathrm{L}^{-1}$ modifier (PP and FePP) in DMF 150 was drop-coated onto unmodified buckypaper surfaces with $\emptyset_{151}$ $=10 \mathrm{~mm}$ (each electrode contains $5.39 \mathrm{mg}$ of MWCNTs) and 152 the resulting electrode left to dry overnight at room 153 temperature. Electrical contact was obtained via a metal wire 154 with carbon paste. The back and sides of the electrode were 155 sealed with silicone paste.

156

Preparation of Redox-Embedded MWCNT Bucky- 157 paper Electrodes by One-Pot Method. A $1 \mathrm{mg} \mathrm{mL}^{-1}{ }_{158}$ MWCNT suspension was first prepared by the addition of 150159 $\mathrm{mg}$ of nonfunctionalized MWCNTs into $150 \mathrm{~mL}$ of DMF. The 160 dispersion was then sonicated for $30 \mathrm{~min}$ prior to addition of 161 the modifier ( $\mathrm{PLQ}, \mathrm{NQ}, \mathrm{PP}$, and FePP). The modifier, 162 dissolved in a minimum volume of DMF, was slowly added 163 into the MWCNT suspension to give a final $0.6 \mathrm{mmol} \mathrm{L}^{-1}$ or 2164 mmol L ${ }^{-1}$ modifier concentration. Prior to filtration, the 165 resulting suspension was sonicated for a further $30 \mathrm{~min}$. After 166 rigorous shaking for $1 \mathrm{~min}, 66 \mathrm{~mL}$ of the suspension was 167 filtered, washed, and dried (as above for the unmodified 168 buckypaper) and the resulting buckypaper cut into electrodes 169 with $\varnothing=10 \mathrm{~mm}$. Electrical contact was obtained via a metal 170 wire with carbon paste. The back and sides of the electrode 171 were sealed with silicone paste.

Preparation of Buckypaper Bioelectrodes. First, 5 mg 173 $\mathrm{mL}^{-1}$ stock solutions of BOD and FADGDH were prepared in 174 $0.1 \mathrm{~mol} \mathrm{~L}^{-1}$ phosphate buffer at $\mathrm{pH} 7.0$ and McIlvaine buffer at 175 pH 7.0 (0.2 mol L ${ }^{-1} \mathrm{Na}_{2} \mathrm{HPO}_{4}, 0.1 \mathrm{~mol} \mathrm{~L}{ }^{-1}$ citric acid), 176 respectively. A total of $150 \mu \mathrm{L}$ of $5 \mathrm{mg} \mathrm{mL}^{-1}$ enzyme solution 177 ( $0.75 \mathrm{mg}$ enzyme) was then added to the surface of a 178 buckypaper with $\varnothing=10 \mathrm{~mm}$, and the enzyme solution was 179 allowed to fully absorb at $4{ }^{\circ} \mathrm{C}$ overnight. The electrode was 180 subsequently rinsed with the corresponding buffer before use. 181

Electrochemistry. Electrochemical measurements were 182 performed at room temperature using an Eco Chemie Autolab 183 PGSTAT 100 potentiostat running GPES 4.9 software or a 184 Biologic VMP3Multi Potentiostat with EC-lab software. For 185 half-cell testing, a conventional three-electrode cell setup was 186 used comprising a buckypaper working electrode $(\varnothing=10 \mathrm{~mm}), 187$ a saturated calomel reference electrode (SCE with sat. $\mathrm{KCl}$ ), 188 and a Pt wire counter-electrode. The complete fuel cell setup 189 comprised a one-pot protoporphyrin buckypaper with BOD 190 biocathode $\left(\mathrm{BP}_{\mathrm{PP}}-\mathrm{BOD}\right)$ and a one-pot phenanthroline 191 quinone buckypaper with FADGDH (BP $\mathrm{PLQ}-\mathrm{FADGDH}) 192$ bioanode immersed in $20 \mathrm{~mL}$ of Mcllvaine buffer at pH 7.0193 with an interelectrode distance of $3 \mathrm{~mm}$. Gas flows were set 194 qualitatively and moderately to obtain reproducible conditions. 195 
196 Average catalytic current densities were obtained by subtracting 197 the background current: the signal obtained without oxygen, for 198 the cathode, and without glucose, for the anode. Fuel cell 199 experiments were performed by recording a linear sweep 200 polarization from the open circuit voltage ( OCV) to $0.02 \mathrm{~V}$ 201 with the anode connected to the counter and reference leads, 202 and the cathode connected to the working lead. Power densities 203 were obtained by dividing the power delivery by the surface 204 area or volume of one electrode.

Scanning Electron Microscopy. Buckypaper electrodes 206 with $\varnothing=3 \mathrm{~mm}$ were imaged using a FEI/Quanta FEG 250 207 scanning electron microscope (Hillsboro, OR, USA) operating 208 at an accelerating voltage of $5 \mathrm{kV}$ without metal coating.

209 Static Water Contact Angles. Water contact angles were 210 obtained at room temperature by delivering a $2 \mu \mathrm{L}$ droplet of 211 distilled water onto the sample surface on a horizontal stage 212 using a Dataphysics OCA 35 system. Multiple droplet 213 measurements ( 8 or 9 ) were recorded per sample type.

\section{RESULTS AND DISCUSSION}

215 Characterization of Unmodified MWCNT and Redox216 Embedded MWCNT Buckypaper Electrodes. Pristine 217 freestanding buckypaper prepared from filtration of CNT 218 dispersions without additives tends to be fragile and difficult to 219 manipulate. Our initial experiments established that the ability 220 to handle pristine unmodified BP was improved when the 221 amount of MWCNTs in the final product was increased by at 222 least a factor of $2 .^{30}$ Redox-embedded BP was subsequently 223 prepared in several steps (see Experimental Section) either by 224 the addition of redox molecules to the MWCNTs dispersion 225 before filtration (one-pot method) or after filtration by drop226 coating onto the unmodified BP (drop-coat method). The BP 227 functionalization is based on $\pi-\pi$ stacking interactions between 228 aromatic groups and CNT sidewalls. For all buckypapers, flat 229 and reproducible disks were obtained after filtration (Figure $2301 \mathrm{~A}$ ), drying, and cutting (Figure $1 \mathrm{~B}$ and $\mathrm{C}$, respectively). BP 231 thicknesses ranged between 230 and $320 \mu \mathrm{m}$ (see Table S1). 232 The variability in thickness results from differences in vacuum 233 pressure and the MWCNTs dispersion.

234 Scanning electron microscopy was performed to evaluate the 235 morphology of unmodified BP (BP, Figure 1D) and BP 236 prepared from the one-pot method with redox molecules: 237 protoporphyrin IX $\left(\mathrm{BP}_{\mathrm{PP}}\right.$, Figure $\left.1 \mathrm{E}\right)$, ferriprotoporphyrin IX $238\left(\mathrm{BP}_{\mathrm{FePP}}\right.$, Figure $\left.1 \mathrm{~F}\right)$, and 1,10-phenanthroline-5,6-dione $239\left(\mathrm{BP}_{\mathrm{PLQ}}\right.$, Figure $\left.1 \mathrm{G}\right)$. The SEM images reveal that the BPs 240 comprise a random and entangled network of MWCNTs with 241 nanoscale porosity. The images show subtle evidence that 242 functionalized BPs have a flatter and more compact topography 243 compared to unmodified BP, suggestive of more intimate 244 interactions between nanotubes in the presence of redox 245 molecules via $\pi-\pi$ stacking.

246 Cyclic voltammograms $(\mathrm{CVs})$ of the $\mathrm{Fe}(\mathrm{CN})_{6}{ }^{3-}$ redox probe 247 recorded at unmodified and $\mathrm{BP}_{\mathrm{PP}}$ paper electrodes reveal a 248 significant increase in peak current with a decrease in peak-to249 peak separation $\left(\Delta E_{\mathrm{P}}\right)$ following modification with proto250 porphyin molecules (see Figure S1). The dramatic enhance251 ment with chemical functionalization is partially attributed to a 252 physical improvement in the electronic connectivity between 253 carbon nanotubes. The increase in peak current observed is also 254 partially attributed to improved diffusion of $\mathrm{Fe}(\mathrm{CN})_{6}^{3-/ 4-}$ in 255 the $3 \mathrm{D}$-structured electrode, facilitated by the increased surface 256 hydrophilicity (Figure S2).

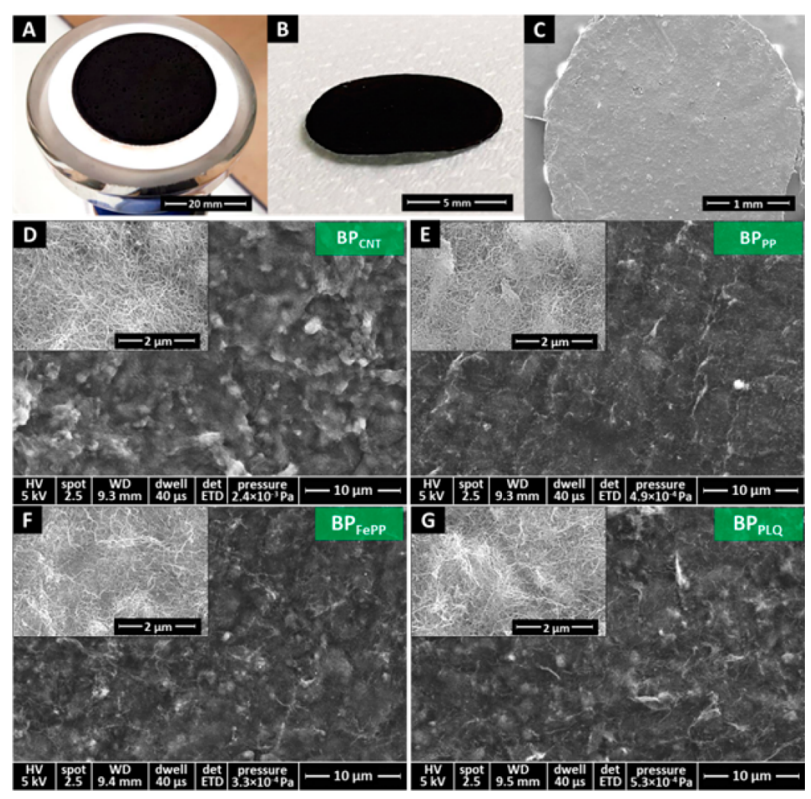

Figure 1. (A, B) Photographs of freshly prepared $\mathrm{BP}_{\mathrm{PP}}$ buckypaper (A) after filtration and (B) after filtration, drying, and cutting into the electrode. (C-G) SEM micrographs of (C, E) $\mathrm{BP}_{\mathrm{PP}},(\mathrm{D}) \mathrm{BP},(\mathrm{F})$ $\mathrm{BP}_{\mathrm{FePP}}$, and $(\mathrm{G}) \mathrm{BP}_{\mathrm{PLQ}}$ buckypaper electrodes recorded at $(\mathrm{C}) 60 \times$, (D-G) 5000× and $40000 \times$ (inset) magnification. All modified electrodes were prepared by the one-pot method.

To investigate the presence and accessibility of porphyrin 257 and PLQ molecules in BP prepared via the one-pot and drop- 258 coat methods, cyclic voltammetry was performed on one-sided 259 BP samples with a geometric surface area of $0.785 \mathrm{~cm}^{2}$. CVs 260 were first recorded at functionalized electrodes prepared by the 261 one-pot method in argon-saturated $0.1 \mathrm{~mol} \mathrm{~L}^{-1}$ phosphate 262 buffer at $\mathrm{pH}$ 7.0. Figure 2 shows $\mathrm{CVs}$ recorded at $\mathrm{BP}_{\mathrm{FePP}}$ and $263 \mathrm{f} 2$ $\mathrm{BP}_{\mathrm{PLQ}}$ prepared via the one-pot method. The CVs reveal the 264 presence of well-defined chemically reversible processes. At 265 $\mathrm{BP}_{\mathrm{FePP}}$, the one-electron $\mathrm{Fe}^{\mathrm{III}} / \mathrm{Fe}^{\mathrm{II}}$ redox couple is observed at 266 $E_{1 / 2}=-0.38 \mathrm{~V}$ vs SCE $\left(10 \mathrm{mV} \mathrm{s}^{-1}\right)$, consistent with reported 267
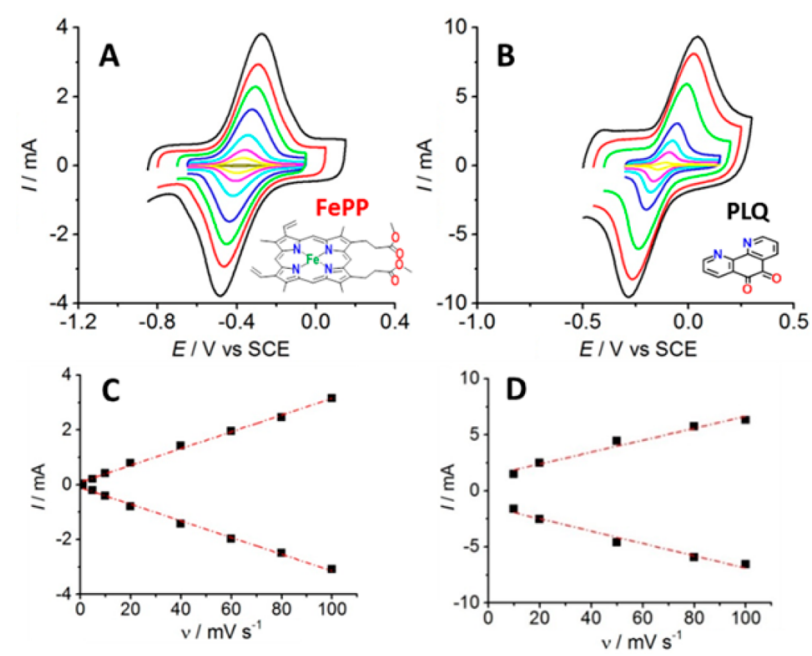

Figure 2. (A,B) CVs recorded at $(\mathrm{A}) \mathrm{BP}_{\mathrm{FePP}}$ and (B) $\mathrm{BP} \mathrm{PLQ}_{\mathrm{PLC}}$ buckypaper electrodes (one-pot method) in Ar saturated $0.1 \mathrm{~mol}$ $\mathrm{L}^{-1}$ phosphate buffer at $\mathrm{pH} 7$ at different scan rates. (C, D) Corresponding plots of anodic and cathodic peak current versus scan rate. 
Table 1. Electrochemical Parameters for $\mathrm{BP}_{\mathrm{FePP}}$ and $\mathrm{BP}_{\mathrm{PLQ}}$ Electrodes Prepared by One-Pot and Drop-Coating Functionalization Methods

\begin{tabular}{|c|c|c|c|c|c|}
\hline buckypaper electrode (number ${ }^{a}$ ) & fabrication method & modifier concentration $\left(\mathrm{mmol} \mathrm{L}^{-1}\right)$ & surface concentration ${ }^{b}\left(10^{-7} \mathrm{~mol} \mathrm{~cm}{ }^{-2}\right)$ & $\Delta E_{\mathrm{p}}(\mathrm{mV})$ & $E_{1 / 2}(\mathrm{~V})$ \\
\hline $\mathrm{BP}_{\mathrm{FePP}}(n=3)$ & one-pot & 0.6 & $1.38 \pm 0.58$ & 65 & -0.37 \\
\hline $\mathrm{BP}_{\mathrm{FePP}}(n=3)$ & drop-coat & 0.6 & $0.48 \pm 0.25$ & 55 & -0.35 \\
\hline $\mathrm{BP}_{\mathrm{FePP}}(n=7)$ & drop-coat & 10 & $6.43 \pm 3.58$ & 215 & -0.36 \\
\hline $\mathrm{BP}_{\mathrm{PLQ}}(n=3)$ & one-pot & 2 & $1.21 \pm 0.30$ & 118 & -0.13 \\
\hline
\end{tabular}

${ }^{a}$ Number of independent buckypaper electrode samples analyzed. ${ }^{b}$ Surface concentrations obtained from the anodic peak of CVs recorded at 10 $\mathrm{mVs}^{-1}$ in Ar.

268 values of $E_{1 / 2}=-0.34 \mathrm{~V}$ and $-0.39 \mathrm{~V}$ vs SCE for FePP 269 modified MWCNTs on GC. ${ }^{33,34}$ At $\mathrm{BP}_{\mathrm{PLQ}}$, the two-electron 270 two-proton o-quinone/o-hydroquinone system is observed at $271 E_{1 / 2}=-0.13 \mathrm{~V}$ vs SCE $\left(10 \mathrm{mV} \mathrm{s}^{-1}\right)$ as previously observed for 272 PLQ adsorbed on MWCNTs on GC electrodes. ${ }^{35}$

273 Well-defined voltammograms and a linear dependence $\left(r^{2}>\right.$ 2740.95 ) of peak current on scan rate for anodic and cathodic 275 peaks are observed at the $\mathrm{BP}_{\mathrm{FePP}}$ and $\mathrm{BP}_{\mathrm{PLQ}}$ electrodes (Figure $2762 \mathrm{C}$ and $\mathrm{D}$ ), confirming that the redox molecules are accessible 277 and surface bound. The stability of the immobilized molecules 278 was tested by subjecting the electrodes to repeat potential 279 cycling at $20 \mathrm{mV} \mathrm{s}^{-1}$ (Figure S3). No noticeable loss in 280 electroactivity was observed after 20 cycles, confirming the high 281 stability of the immobilized redox groups and the bulk 282 nanotube structure despite the noncovalent modification 283 approach.

284 Modified $\mathrm{BP}_{\mathrm{FePp}}$ electrodes prepared by the drop-coat 285 method were also examined by voltammetry and gave the 286 expected electroactivity as observed for the one-pot method. $287 \mathrm{BP}_{\mathrm{FePP}}$ electrodes were prepared by drop-coating $150 \mu \mathrm{L}$ of 0.6 $288 \mathrm{mmol} \mathrm{L}^{-1}$ or $10 \mathrm{mmol} \mathrm{L}^{-1} \mathrm{FePP}$ DMF solutions onto pristine 289 unmodified BPs $(\varnothing=10 \mathrm{~mm})$. The electrochemical parameters 290 obtained from CVs recorded in phosphate buffer at $\mathrm{pH} 7.0$ and $29110 \mathrm{mV} \mathrm{s}^{-1}$ are listed in Table 1 .

292 Examination of the data in Table 1 reveals that one-pot $293 \mathrm{BP}_{\mathrm{FePP}}$ exhibits a higher surface concentration than drop-coat $294 \mathrm{BP}_{\mathrm{FePP}}\left(1.38 \pm 0.58\right.$ versus $\left.0.48 \pm 0.25 \times 10^{-7} \mathrm{~mol} \mathrm{~cm}^{-2}\right)$ when 295 the same initial modifier concentration is used, consistent with 296 effective bulk functionalization via the one-pot method. 297 Increasing the modifier concentration from $0.6 \mathrm{mmol} \mathrm{L}^{-1}$ to $29810 \mathrm{mmol} \mathrm{L}^{-1}$ resulted in a very high surface concentration of $2996.43 \pm 3.58 \times 10^{-7} \mathrm{~mol} \mathrm{~cm}{ }^{-2}$, highlighting the possibility to 300 tailor redox molecule loading in the paper electrodes. It is 301 expected that such high surface concentrations would be 302 possible via the one-pot method with a $10 \mathrm{mmol} \mathrm{L}^{-1}$ modifier 303 concentration. However, this was not explored due to the high 304 volumes and quantity of modifier required for one-pot 305 buckypaper fabrication. The surface concentrations for FePP 306 prepared here are significantly higher than previously reported 307 values of $6.8 \times 10^{-10} \mathrm{~mol} \mathrm{~cm}^{-2}$ and $1.1 \times 10^{-9} \mathrm{~mol} \mathrm{~cm}^{-2}$ for 308 FePP modified MWCNTs on GC. ${ }^{33,34}$ The high loadings 309 observed here are consistent with an effective high surface area 310 3D-structured matrix.

311 Table 1 also reveals that $\mathrm{BP}_{\mathrm{FePp}}$ prepared via one-pot and 312 drop-coat methods with $0.6 \mathrm{mmol} \mathrm{L}^{-1}$ modifier solution give 313 similar peak-to-peak separation values of $\leq 65 \mathrm{mV}$ and therefore 314 similar apparent electron transfer kinetics. Significantly larger $315 \Delta E_{\mathrm{P}}$ values and therefore sluggish electron transfer kinetics 316 were observed for highly functionalized $\mathrm{BP}_{\mathrm{FePP}}$ electrodes 317 prepared with $10 \mathrm{mmol} \mathrm{L}^{-1}$ of the modifier. This is consistent 318 with an extensive network of redox molecules being deeply embedded in the CNT structure, which would increase electron 319 tunneling distances and film resistivity.

On the basis of the $\mathrm{BP}_{\mathrm{FePP}}$ optimization experiments, we 321 prepared PLQ buckypaper via the one-pot method using a 322 modestly high concentration of $2 \mathrm{mmol} \mathrm{L}^{-1}$. No further 323 optimization was performed. The surface concentration 324 obtained for one-pot $\mathrm{BP}_{\mathrm{PLQ}}$ was $1.21 \pm 0.30 \times 10^{-7} \mathrm{~mol} 325$ $\mathrm{cm}^{-2}$, which reveals the possibility to obtain high redox 326 molecule loadings with a near $1 \times 10^{-7} \mathrm{~mol} \mathrm{~cm}^{-2} 327$ concentration. The $\Delta E_{\mathrm{P}}$ value of $118 \mathrm{mV}$ observed for $\mathrm{BP}_{\mathrm{PLQ}} 328$ is consistent with a slow rate of electron transfer, increased BP 329 resistivity, and a large degree of potential inversion for the two- 330 electron two-proton quinone process. ${ }^{36}$

331

Bioelectrocatalytic $\mathrm{O}_{2}$ Reduction at $\mathrm{BP}_{\mathrm{pp}}$ Electrodes 332 with Immobilized BOD Enzyme from Myrothecium 333 verrucaria. For biocathode construction, the multicopper 334 oxidase (MCO) enzyme BOD from Myrothecium verrucaria 335 $(\mathrm{Mv})$ was employed as the catalyst for the four-electron 336 reduction of $\mathrm{O}_{2}$ to $\mathrm{H}_{2} \mathrm{O}$. BOD is a promising enzyme for 337 biofuel cells due to its high bioelectrocatalytic activity under 338 mild conditions and formal potential close to that of the $\mathrm{O}_{2} / 339$ $\mathrm{H}_{2} \mathrm{O}$ couple $(0.816 \mathrm{~V}$ vs $\mathrm{RHE}$ at $\mathrm{pH} 0)$. Bilirubin, as a natural 340 substrate for $\mathrm{BOD}$, and its analogues, have been attached to 341 MWCNT electrodes to facilitate DET with $\mathrm{MvBOD}$ for $\mathrm{O}_{2} 342$ reduction. ${ }^{34,37}$ The interaction is supported by favorable 343 immobilization and orientation. However, a commonly 344 accepted problem with BOD is that significant catalytic activity 345 loss is observed in the presence of $\mathrm{H}_{2} \mathrm{O}_{2}$, a common byproduct 346 of oxidase enzymes found in glucose $/ \mathrm{O}_{2}$ biofuel cells. The use 347 of $\mathrm{O}_{2}$-insensitive $\mathrm{FADGDH}$ in biofuel cell design can 348 circumvent this issue.

349

In this study, the porphyrin-BOD system was exploited for 350 the development of buckypaper cathodes. One-pot $\mathrm{BP}_{\mathrm{pp}} 351$ electrodes were first prepared then incubated with BOD, 352 washed with phosphate buffer at $\mathrm{pH} 7.0$, then tested for 353 enzyme presence and activity. Figure $3 \mathrm{~A}$ and $\mathrm{B}$ show CVs $354 \mathrm{f} 3$ recorded in argon and oxygen at one-pot $\mathrm{BP}_{\mathrm{PP}}-\mathrm{BOD}$ and $\mathrm{BP}-355$ $\mathrm{BOD}$, respectively. Under oxygen, both types of electrode 356 exhibited similar onset potential of $E_{\text {onset }}=0.54 \pm 0.01 \mathrm{~V}$ vs 357 SCE and $0.52 \pm 0.01 \mathrm{~V}$ vs SCE, respectively. The onset 358 potentials are close to that of the predicted T1 copper site of 359 $M v \mathrm{BOD}$ responsible for substrate oxidation and successive 360 electron transfers $\left(E_{1 / 2(\mathrm{~T} 1)}=0.48 \mathrm{~V}\right.$ vs SCE at $\left.\mathrm{pH} 7.0\right) .{ }^{34}$ The 361 onset potentials are close to the ideal thermodynamic reduction 362 potential for $\mathrm{O}_{2}$ of $0.572 \mathrm{~V}$ vs SCE at $\mathrm{pH} 7.0$ (assuming a 363 potential difference of $244 \mathrm{mV}$ between RHE and SCE 364 reference electrodes). The onset potential values are therefore 365 very attractive for biofuel cell applications and consistent with 366 efficient single-proton single-electron DET between the BP and 367 the enzyme.

The catalytic wave observed in oxygen at $\mathrm{BP}_{\mathrm{PP}}$ confirms DET 369 accompanied by the electrocatalytic reduction of oxygen via 370 


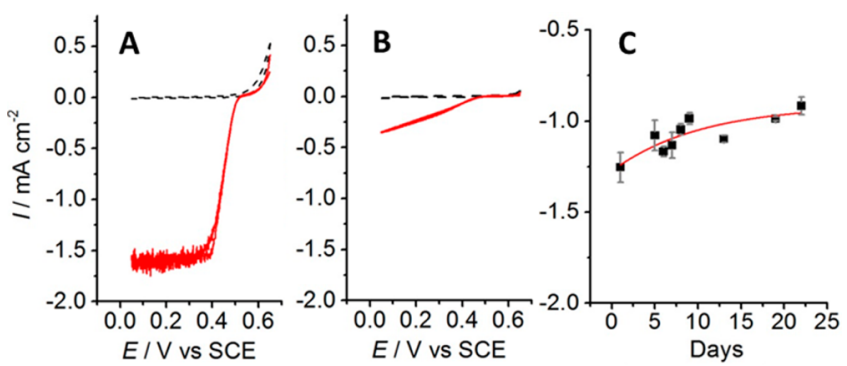

Figure 3. $(A, B) C V s$ of bioelectrocatalytic $\mathrm{O}_{2}$ reduction recorded at (A) $\mathrm{BP}_{\mathrm{PP}}$ (one-pot method) and (B) BP buckypaper electrodes after BOD enzyme immobilization in (--) Ar saturated and (-) $\mathrm{O}_{2}$ saturated $0.1 \mathrm{~mol} \mathrm{~L}^{-1}$ phosphate buffer at $\mathrm{pH} 7.0$ at scan rate $=0.2$ $\mathrm{mV} \mathrm{s}^{-1}$. (C) Evolution of maximum catalytic current density as a function of time for $\mathrm{BP}_{\mathrm{PP}}-\mathrm{BOD}$. Chronoamperograms recorded at $E_{\text {app }}$ $=0.2 \mathrm{~V}$ vs SCE and current densities obtained after $30 \mathrm{~min}$. Error bars correspond to one standard deviation from two electrodes.

371 BOD. On the basis of repeat measurements, an average 372 maximum current density of $0.34 \pm 0.15 \mathrm{~mA} \mathrm{~cm}^{-2}$ is observed 373 at $\mathrm{BP}$ compared to $1.33 \pm 0.17 \mathrm{~mA} \mathrm{~cm}{ }^{-2}$ for $\mathrm{BP}_{\mathrm{PP}}$ (one-pot 374 method), confirming substantially enhanced performance for 375 the protoporphyrin buckypaper. At BP, an ill-defined "residual 376 slope" current is observed in oxygen, attributed to unfavorable 377 orientation of adsorbed enzymes. In contrast, at the $\mathrm{BP}_{\mathrm{PP}}$ 378 electrode, well-defined steady-state voltammograms are ob379 served consistent with fast mass transport, enzyme catalysis, 380 and heterogeneous electron transfer at the buckypaper 381 electrode. $^{37}$ It is noted that a scan rate of $0.2 \mathrm{mV} \mathrm{s}^{-1}$ was 382 employed due to the superior steady-state signals with low 383 capacitance (see Figure S4 for catalytic currents recorded at 384 different scan rates). A summary of the catalytic parameters 385 obtained at different bioelectrodes is shown in Table 2 .

Table 2. Catalytic Parameters for $\mathrm{BP}_{\mathrm{PP}}-\mathrm{BOD}$ Cathode and BP $_{\text {PLQ }}$-FADGDH Anode Prepared by One-Pot and DropCoating Functionalization Methods

\begin{tabular}{|c|c|c|c|}
\hline $\begin{array}{l}\text { buckypaper } \\
\text { electrode } \\
\text { (number }{ }^{a} \text { ) }\end{array}$ & $\begin{array}{l}\text { fabrication method } \\
\text { (modifier } \\
\text { concentration) }\end{array}$ & $\begin{array}{l}\text { onset potential } \\
(\mathrm{V})^{b}\end{array}$ & $\begin{array}{c}\text { maximum catalytic } \\
\text { current } \\
\left.(\mathrm{mA} \mathrm{cm})^{-2}\right)^{b, c}\end{array}$ \\
\hline $\begin{array}{c}\mathrm{BP}_{\mathrm{PP}}-\mathrm{BOD} \\
(n=5)\end{array}$ & $\begin{array}{r}\text { one-pot }(0.6 \\
\left.\text { mmol L } \mathrm{L}^{-1}\right)\end{array}$ & $0.54 \pm 0.01$ & $1.33 \pm 0.17$ \\
\hline $\begin{array}{c}\mathrm{BP}_{\mathrm{PP}}-\mathrm{BOD} \\
(n=3)\end{array}$ & $\begin{array}{c}\text { drop-coat }(0.6 \\
\text { mmol L }\end{array}$ & $0.54 \pm 0.01$ & $1.10 \pm 0.14$ \\
\hline $\begin{array}{c}\mathrm{BP}_{\mathrm{PP}}-\mathrm{BOD} \\
(n=3)\end{array}$ & $\begin{array}{c}\text { drop-coat }(10 \\
\left.\mathrm{mmol} \mathrm{L}^{-1}\right)\end{array}$ & $0.54 \pm 0.01$ & $1.26 \pm 0.11$ \\
\hline $\begin{array}{l}\text { BP-BOD } \\
\quad(n=3)\end{array}$ & unmodified & $0.52 \pm 0.01$ & $0.34 \pm 0.15$ \\
\hline $\begin{array}{l}\mathrm{BP}_{\mathrm{PLQ}^{-}} \\
\quad \mathrm{FADGDH} \\
(n=5)\end{array}$ & $\begin{array}{l}\text { one-pot }(2 \\
\text { mmol L } \\
-1)\end{array}$ & $-0.23 \pm 0.01$ & $5.38 \pm 0.54$ \\
\hline $\begin{array}{l}\text { BP-FADGDH } \\
(n=2)\end{array}$ & unmodified & $-0.01 \pm 0.00$ & $0.002 \pm 0.001$ \\
\hline \multicolumn{4}{|c|}{$\begin{array}{l}{ }^{a} \text { Number of independent buckypaper electrode samples analyzed. } \\
{ }^{b} \text { Parameters obtained from the forward sweep of CVs recorded at } 0.2 \\
\mathrm{mV} \mathrm{s}^{-1} \cdot{ }^{c} \text { Current obtained at } 0.2 \text { and } 0.15 \mathrm{~V} \text { at BOD and FADGDH } \\
\text { electrodes, respectively. }\end{array}$} \\
\hline
\end{tabular}

386 The long-term stability of $\mathrm{BP}_{\mathrm{PP}}-\mathrm{BOD}$ was also assessed by 387 periodically recording chronoamperograms at $E_{\text {app }}=0.2 \mathrm{~V}$ vs 388 SCE for $30 \mathrm{~min}$ over 24 days of storage in phosphate buffer at $389 \mathrm{pH} 7.0$ (Figure S5). The corresponding plot in Figure 3C of the 390 maximum catalytic current obtained on different days reveals 391 remarkable stability for $\mathrm{BP}_{\mathrm{PP}}-\mathrm{BOD}$, with the current density decreasing by $10 \%$ over the first 7 days and $27 \%$ over 24 days. 392 Stability experiments performed in a similar manner at other 393 MWCNT-MCO enzyme cathodes report 40-45\% current loss 394 after 1 week and 45-60\% after 20-24 days. ${ }^{38,39}$ To clarify, such 395 stability experiments evaluate both operational stability (for 30396 min per day) and storage stability. The enhanced stability 397 observed here compared to that with CNT-modified GC 398 electrodes is consistent with improved physical enzyme 399 entrapment into the nanopore-containing CNT matrix via 400 fixation and/or dynamic reorganization effects. ${ }^{40}$ mo1

A brief assessment of the bioelectrocatalytic performance of 402 $\mathrm{BP}_{\mathrm{PP}}-\mathrm{BOD}$ was also performed to demonstrate enzyme 403 inhibition at the biocathode. CVs recorded in the presence 404 and absence of $40 \mathrm{mmol} \mathrm{L}^{-1} \mathrm{H}_{2} \mathrm{O}_{2}$ in phosphate buffer at $\mathrm{pH} 405$ 7.0 in oxygen are shown in Figure S6 and clearly reveal the loss 406 of oxygen reduction current due to inhibition of immobilized 407 bilirubin oxidase by $\mathrm{H}_{2} \mathrm{O}_{2}$. The catalytic current was suppressed 408 in the presence of $\mathrm{H}_{2} \mathrm{O}_{2}$ and remained suppressed after transfer 409 to a fresh phosphate buffer solution, confirming that the 410 enzyme's activity was inhibited and not restored. The absence 411 of oxygen reduction in these experiments validates the 412 importance of the active "wired" enzyme as the biocatalyst. 413 Chronoamperometry performed at $\mathrm{BP}_{\mathrm{PP}}-\mathrm{BOD}$ in phosphate 414 buffer at $\mathrm{pH} 7.0$ in oxygen (Figure $\mathrm{S} 6$ ) revealed the rapid 415 nature of enzyme inhibition by $\mathrm{H}_{2} \mathrm{O}_{2}$ and the good stability of 416 the biocathode in the presence of a physiologically relevant 417 concentration of $\mathrm{NaCl}(100 \mathrm{mM})$.

The bioelectrocatalytic performance of $\mathrm{BP}_{\mathrm{PP}}$ for oxygen 419 reduction was also performed at electrodes prepared by the 420 drop-coat method. No significant difference in $E_{\text {onset }}$ was 421 observed between drop-coat and one-pot $\mathrm{BP}_{\mathrm{PP}}$ electrodes. 422 Likewise, equivalent sigmoidal steady-state current responses 423 (with different current magnitudes) were observed for all $\mathrm{BP}_{\mathrm{PP}} 424$ electrodes. For drop-coat $\mathrm{BP}_{\mathrm{PP}}$, the maximum average catalytic 425 current only slightly increased from $1.10 \pm 0.14$ to $1.26 \pm 0.11426$ $\mathrm{mA} \mathrm{cm}{ }^{-2}$ with an increase in protoporphyrin modifier from 0.6427 mmol L ${ }^{-1}$ to $10 \mathrm{mmol} \mathrm{L}^{-1}$.

The best performing biocathode identified here was the 429 $\mathrm{BP}_{\mathrm{Pp}}$-BOD prepared using the one-pot method with $I_{\max }=1.33430$ $\pm 0.17 \mathrm{~mA} \mathrm{~cm}^{-2}$. The high performance of this biocathode is 431 clear given that typical values obtained by our group and others 432 for CNT paper-based MCO cathodes are 0.17 to $1.1 \mathrm{~mA} \mathrm{~cm}^{-2} 433$ in oxygen-saturated solution. ${ }^{27,29,30,41,42}$

Bioelectrocatalytic Glucose Oxidation at BP $\mathrm{PLQ}$ Elec- 435 trodes with Immobilized FADGDH from Aspergillus sp. 436 For bioanode development, the one-pot method was exploited 437 for preparation of a new type of redox-embedded buckypaper 438 with immobilized FADGDH. To prepare the anode, a 439 MWCNT dispersion containing $2 \mathrm{mmol} \mathrm{L}^{-1}$ of $1,10-440$ phenanthroline-5,6-dione (PLQ) was used. The bioanode was 441 obtained by drop-casting $150 \mu \mathrm{L}$ of $5 \mathrm{mg} \mathrm{mL}^{-1}$ enzyme 442 solution onto the $\mathrm{BP}_{\mathrm{PLQ}}$ and leaving the solution overnight 443 until the droplet had fully adsorbed. The PLQ molecule has 444 previously been reported as a mediator for the cofactors 445 $\mathrm{NADH} / \mathrm{NADPH}$ coupled with NAD/NADP-dependent en- 446 zymes. $^{35,43}$ To the best of our knowledge, the phenanthroline 447 quinone as a free ligand has not been demonstrated as a 448 mediator for FAD-dependent enzymes such as FADGDH. In 449 addition to the low redox potentials, a major advantage of 450 phenanthroline quinone mediators is their nonreactivity toward 451 active-site enzyme amine and thiol groups. ${ }^{43}$ In this work, we 452 have investigated the use of PLQ in the form of a redox- 453 embedded functionalized buckypaper, to electrically connect 454 

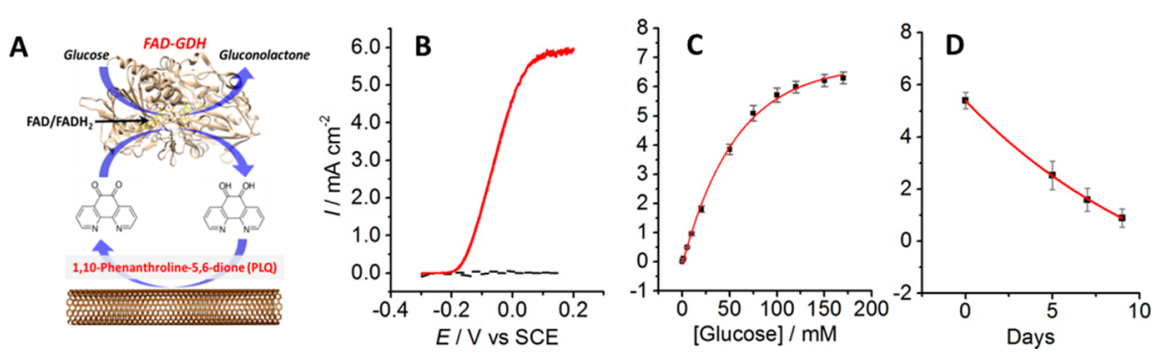

Figure 4. (A) Scheme illustrating bioelectrocatalytic oxidation of glucose on $\mathrm{BP}_{\mathrm{PLQ}}$ buckypaper via MET with the active site of FADGDH. (B) CVs recorded at a $\mathrm{BP}_{\mathrm{PLQ}}$ buckypaper electrode after FADGDH immobilization in (--) $0 \mathrm{mmol} \mathrm{L}^{-1}$ and (-) $170 \mathrm{mmol} \mathrm{L}^{-1}$ glucose in Ar saturated Mcllvaine buffer at $\mathrm{pH} 7.0$ at scan rate $=0.2 \mathrm{mV} \mathrm{s}^{-1}$. (C) Plot of average current density obtained for different glucose concentrations recorded at three $\mathrm{BP}_{\mathrm{PLQ}}-\mathrm{FADGDH}$ electrodes. (D) Evolution of maximum catalytic current density as a function of time for BP $\mathrm{PLQ}^{-\mathrm{FADGDH}}$ with $170 \mathrm{mmol}$ $\mathrm{L}^{-1}$ glucose. (C, D) Chronoamperograms recorded at $E_{\text {app }}=0.15 \mathrm{~V}$ vs SCE and current densities obtained after 30 min. Error bars correspond to one standard deviation from at least two electrodes.

455 the active site of FADGDH to the electrode for bioelec456 trocatalytic oxidation of glucose (see Figure $4 \mathrm{~A}$ ). In this 457 mechanism, the FADGDH oxidizes the $\beta$-D-glucose to D458 glucono-1,5-lactone using the FAD cofactor, which itself is 459 reduced to $\mathrm{FADH}_{2}$. The PLQ mediator then acts as a 460 secondary electron acceptor to oxidize the reduced cofactor, ${ }_{461} \mathrm{FADH}_{2}$. The mediator is finally reoxidized by the electrode 462 which is set at an appropriate oxidizing potential.

463 Figure 4B and Figure S7 show CVs recorded in 0 (--) and $464170 \mathrm{mmol} \mathrm{L}^{-1}(-)$ glucose in McIlvaine buffer at $\mathrm{pH} 7.0$ at 465 one-pot $\mathrm{BP}_{\mathrm{PLO}}$-FADGDH and BP-FADGDH electrodes, 466 respectively. In the presence of $170 \mathrm{mmol} \mathrm{L}^{-1}$ glucose, an 467 onset potential of $E_{\text {onset }}=-0.23 \pm 0.01 \mathrm{~V}$ vs SCE is observed at $468 \mathrm{BP}_{\mathrm{PLQ}}$-FADGDH, which is attractively low for a glucose469 oxidizing bioanode and similar to that obtained using 1,4 470 naphthoquinone hydrogel mediators with FADGDH $\left(E_{\text {onset }}=\right.$ $471-0.18$ to $-0.25 \mathrm{~V}$ vs SCE at near neutral $\mathrm{pH})^{22,23}$ 472 Interestingly, the onset potential of $-0.23 \mathrm{~V}$ is much more 473 negative than the $\approx-0.05 \mathrm{~V}$ previously reported using a $\mathrm{Ru}-$ $474 \mathrm{PLQ}$ polymer with FADGDH, ${ }^{20}$ highlighting an advantage of 475 using the free PLQ mediator in this form. The onset potential is 476 around $180 \mathrm{mV}$ positive of the estimated redox potential of $477-0.41 \mathrm{~V}$ vs SCE for the enzyme-bound relay, $\mathrm{FAD} / \mathrm{FADH}_{2}$, 478 consistent with thermodynamically attractive electron wiring. ${ }^{22}$ 479 The onset potential at $\mathrm{BP}_{\mathrm{PLQ}}$ for glucose oxidation is also about $480200 \mathrm{mV}$ more negative than ferrocene and osmium mediator481 modified electrodes with $E_{\text {onset }} \approx-0.05$ to $0.15 \mathrm{~V}$ vs $482 \mathrm{SCE},{ }^{17,19,21}$ and thus PLQ is an attractive mediator for biofuel 483 cell applications.

484 The voltammograms recorded at $\mathrm{BP}_{\mathrm{PLQ}}$ under argon in the 485 absence and presence of $170 \mathrm{mmol} \mathrm{L}^{-1}$ glucose clearly 486 demonstrate a drastic increase in current signal with glucose 487 addition. Well-defined sigmoidal waves are observed at $0.2 \mathrm{mV}$ $488 \mathrm{~s}^{-1}$ consistent with electrocatalytic oxidation of glucose. A 489 maximum current density of $5.38 \pm 0.54 \mathrm{~mA} \mathrm{~cm}^{-2}$ is observed 490 at $0.15 \mathrm{~V}$ at $\mathrm{BP}_{\mathrm{PLQ}}$ without stirring. In contrast, voltammograms 491 recorded at BP under the same conditions reveal a negligible 492 maximum current density of $0.002 \pm 0.001 \mathrm{~mA} \mathrm{~cm}$. The 493 substantial enhancement in catalytic current provides compel494 ling evidence for mediated electron transfer reaction via PLQ. 495 The high catalytic currents obtained were subsequently 496 validated by comparison with a CNT paper prepared using a 497 known mediator for FADGDH. A 1,4 naphthoquinone 498 buckypaper, $\mathrm{BP}_{\mathrm{NQ}}-\mathrm{FADGDH}$, was prepared and tested in the 499 same manner as for $\mathrm{BP}_{\mathrm{PLQ}^{-}}-\mathrm{FADGDH}$. Voltammetry revealed a 500 significantly smaller maximum current density of $2.20 \mathrm{~mA} \mathrm{~cm}^{-2}$ 501 (Figure S8). Despite being less powerful than the $\mathrm{BP}_{\mathrm{PLQ}}$ electrode, the $\mathrm{BP}_{\mathrm{NQ}}$ electrode still exceeds recent high 502 performance NQ-anodes. ${ }^{22,23}$

The catalytic current obtained of $5.38 \pm 0.54 \mathrm{~mA} \mathrm{~cm}^{-2}$ at 504 $0.15 \mathrm{~V}$ vs SCE for $\mathrm{BP}_{\mathrm{PLQ}}$ in unstirred solution exceeds the 505 performance of that observed at most bioanodes to date 506 without the use of hydrodynamic conditions. We believe that 507 the $\mathrm{BP}_{\mathrm{PLQ}}$ anode exhibits the highest catalytic density for 508 glucose oxidation of any paper-based bioanode. At phenothia- 509 zine-modified commercial buckypaper with immobilized NAD- 510 dependent GDH and NAD cofactor, current densities up to 2.6511 $\mathrm{mA} \mathrm{cm}{ }^{-2}$ at $25^{\circ} \mathrm{C}$ have been reported. ${ }^{25}$ With the addition of 1512 mmol L-1 $\mathrm{NAD}^{+}$in solution, the catalytic current increased to 513 $4.5 \mathrm{~mA} \mathrm{~cm}^{-2}$ at a high potential of $0.35 \mathrm{~V}$. In addition to the 514 high potential required, the use of NAD in solution is less 515 convenient than if the cofactor is surface-bound or enzyme- 516 bound. High performing bioanode architectures typically 517 produce no more than $2 \mathrm{~mA} \mathrm{~cm}^{-22,44,45}$ with the exception 518 of a hierarchical porous carbon bioelectrode which exibited 519 enormous densities up to $100 \mathrm{~mA} \mathrm{~cm}{ }^{-2}$ with rapid 520 convection..$^{18}$ With CNT-modified Toray papers with immo- 521 bilized glucose oxidase and dehydrogenases, current densities in 522 the range $1-3.3 \mathrm{~mA} \mathrm{~cm}^{-2}$ have been reported. ${ }^{23,46-48} 523$

Evaluation of the steady-state current at a fixed potential of 524 $0.15 \mathrm{~V}$ as a function of glucose concentration reveals a linear 525 increase in the range $1 \mathrm{mmol} \mathrm{L}^{-1}$ to $50 \mathrm{mmol} \mathrm{L}^{-1}$ (see 526 calibration plot in Figure S9). As a side note, the linearity of $r^{2}{ }_{527}$ $=0.996$ and the ability to detect beyond the upper limit of 30528 mmol L $\mathrm{L}^{-1}$ means that the $\mathrm{BP}_{\mathrm{PLQ}^{-}}-\mathrm{FADGDH}$ meets basic 529 requirements for a commercial glucose sensor.

Figure $4 \mathrm{C}$ shows that the steady-state currents increased with 531 increasing concentration to a plateau at $170 \mathrm{mmol} \mathrm{L}^{-1}$ glucose; 532 hence $170 \mathrm{mmol} \mathrm{L}^{-1}$ was adopted in experiments as the 533 concentration to maximize catalytic current output, limited by 534 the enzymatic reaction and catalyst surface coverage. Limiting 535 current values were reached within $30 \mathrm{~s}$ (Figure S10), 536 consistent with fast mass transport of glucose at the electrode. 537 Estimated values for the apparent Michaelis-Menten and 538 velocity constants of $K_{\mathrm{m}}=40.4 \mathrm{mmol} \mathrm{L}^{-1}$ and $V_{\max }=6.1 \mathrm{~mA} 539$ $\mathrm{cm}^{-2}$, respectively, are obtained. The estimated $K_{\mathrm{m}}$ is similar to 540 that observed for fungal FADGDHs $\left(K_{\mathrm{m}}=35 \mathrm{mmol} \mathrm{L}^{-149}\right), 541$ and hence the $\mathrm{BP}_{\mathrm{PLQ}}$ electrode maximizes electrocatalysis 542 without significantly affecting the enzymes' binding constant for 543 glucose.

The stability of the $\mathrm{BP}_{\mathrm{PLQ}}$-FADGDH bioanode was assessed 545 over 10 days by periodically recording chronoamperograms at 546 $E_{\text {app }}=0.15 \mathrm{~V}$ vs SCE for $30 \mathrm{~min}$ in Mcllvaine buffer at $\mathrm{pH} 7.0547$ (Figure S11). The plot in Figure 4D of the maximum catalytic 548 
549 current obtained on different days reveals that the bioanode is 550 significantly less stable than the biocathode. After 2 days, $75 \%$ 551 of the original current remains. After 5 days, only $48 \%$ of the 552 initial current remains. Similar storage stability for an 553 FADGDH electrode has previously been observed using an 554 Os polymer mediator with $80 \%$ of the initial current observed 555 after 2 days followed by a rapid breakdown to $56 \%$ after 6 556 days. ${ }^{13}$ This finding suggests that PLQ may be no less toxic or 557 inhibitory toward FADGDH than osmium polymers. Despite 558 the poor stability, high maximum current densities of $\approx 1 \mathrm{~mA}$ $559 \mathrm{~cm}^{-2}$ are nevertheless possible after 10 days, confirming that 560 the $\mathrm{BP}_{\mathrm{PLQ}}$ is operational for several days.

561 Assessment of the bioelectrocatalytic performance of $\mathrm{BP}_{\mathrm{PLQ}^{-}}$ 562 FADGDH was also performed to explore enzyme inhibition at 563 the bioanode. CVs recorded before and after the addition of 10 $564 \mathrm{mmol} \mathrm{L}^{-1}$ of $\mathrm{CuCl}_{2}$ in Mcllvaine buffer at $\mathrm{pH} 7.0$ are shown in 565 Figure S12 and clearly reveal the loss of glucose oxidation 566 current due to inhibition of immobilized FADGDH, attributed 567 to binding of $\mathrm{Cu}^{2+}$ to the $\mathrm{FADH}_{2}$ cofactor as previously 568 observed for glucose oxidase. ${ }^{50}$ The possibility to reverse the 569 enzyme inhibition by addition of a strong metal chelator to 570 reverse binding of the metal ions to $\mathrm{FAD}$ was also tested. The 571 voltammogram obtained after addition of an excess of 572 ethylenediaminetetracetic acid (EDTA, $11 \mathrm{mmol} \mathrm{L}^{-1}$ ) and 573 mild stirring shows an increase in the catalytic oxidation current 574 on the reverse sweep, attributed to partial reactivation of the 575 biocatalyst.

576 Single Compartment Biofuel Cell with a $\mathrm{BP}_{\mathrm{PP}}-\mathrm{BOD}$ ${ }_{577}$ Cathode and $\mathrm{BP}_{\mathrm{PLQ}}-\mathrm{FADGDH}$ Anode Prepared via One578 Pot Fabrication. Power generation from membraneless 579 glucose/oxygen biofuel cells using redox-embedded bucky580 papers was subsequently investigated. A single-compartment 581 glucose $/ \mathrm{O}_{2}$ paper-based biofuel cell was constructed using a $582 \mathrm{BP}_{\mathrm{PP}}-\mathrm{BOD}$ cathode and a $\mathrm{BP}_{\mathrm{PLQ}}-\mathrm{FADGDH}$ anode prepared via
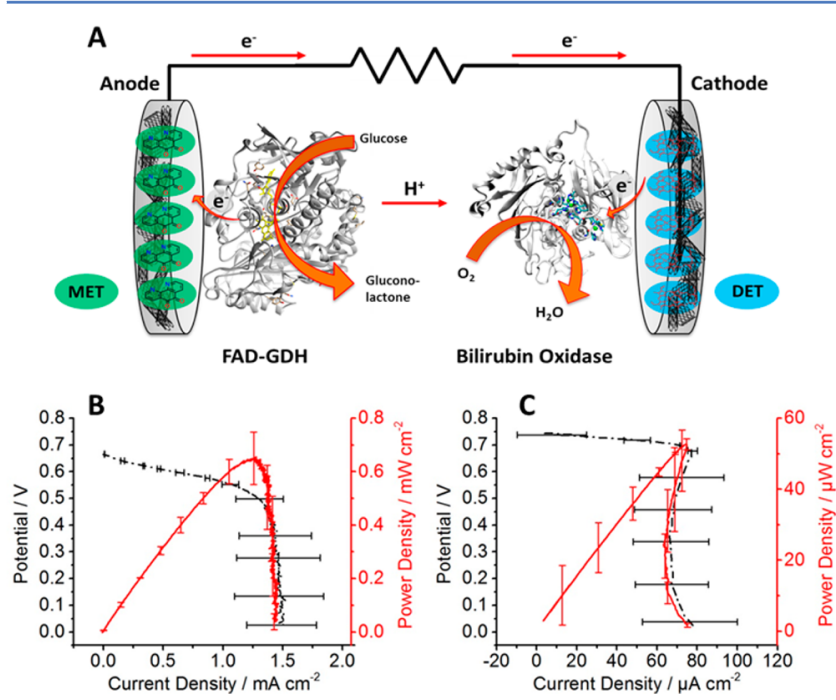

Figure 5. (A) Scheme illustrating the single compartment buckypaper biofuel cell comprising an $\mathrm{O}_{2}$ reducing $\mathrm{BP}_{\mathrm{PP}}$ - $\mathrm{BOD}$ cathode and glucose oxidizing $\mathrm{BP}_{\mathrm{PLQ}}$-FADGDH anode. (B, C) Biofuel cell polarization (-.-) and power curves $(-)$ recorded under $(\mathrm{B})$ oxygen-saturated and $(\mathrm{C})$ quiescent oxygen conditions in Mcllvaine buffer at $\mathrm{pH} 7.0$ with 170 $\mathrm{mmol} \mathrm{L}{ }^{-1}$ glucose. Polarization voltammograms were recorded at 0.2 $\mathrm{mV} \mathrm{s}^{-1}$. Error bars correspond to one standard deviation from three biofuel cells. recorded at $0.2 \mathrm{mV} \mathrm{s}^{-1}$ in McIlvaine buffer at $\mathrm{pH} 7.0$ to evaluate 584 the performance under oxygen-saturated $\left(\approx 1.1 \mathrm{mmol} \mathrm{L}^{-1}\right)$ and 585 quiescent oxygen conditions $\left(\approx 0.23 \mathrm{mmol} \mathrm{L}{ }^{-1}\right)$ with 170586 mmol L ${ }^{-1}$ glucose. ${ }^{51}$ Large OCVs of $0.74 \pm 0.01 \mathrm{~V}$ and $0.67 \pm 587$ $0.01 \mathrm{~V}$ were obtained under quiescent and oxygen-saturated 588 conditions, respectively. The OCVs match closely the estimated 589 maximum voltage of $0.77 \mathrm{~V}$ from the half-cell polarization 590 experiments. The difference in OCV between the quiescent and 591 oxygen-saturated conditions is attributed to a small amount of 592 degradation between fuel cell testing experiments.

593

Average polarization and power curves (Figure 5B and C) 594 reveal a maximum power density of $0.65 \pm 0.10 \mathrm{~mW} \mathrm{~cm}^{-2}$ or 595 $24.07 \mathrm{~mW} \mathrm{~cm}^{-3}$ at $0.5 \mathrm{~V}$ for the biofuel cell under oxygen- 596 saturated conditions without stirring. Under quiescent oxygen 597 with no stirring, a maximum power density of $0.053 \mathrm{~mW} \mathrm{~cm}^{-2} 598$ or $1.97 \mathrm{~mW} \mathrm{~cm}^{-3}$ is observed. The power outputs for these 599 glucose $/ \mathrm{O}_{2}$ biofuel cells are either very good or exceptional 600 depending on whether the power delivery is divided by the 601 surface area $\left(\mathrm{cm}^{2}\right)$ or volume $\left(\mathrm{cm}^{3}\right)$. It is noted that we used 602 equal sized anodes and cathodes in this work and that the 603 power densities were obtained by dividing the power delivery 604 by either the surface area or volume of one electrode. Given 605 that buckypaper is a three-dimensional electrode and size is a 606 crucial parameter for portable biofuel cell applications, the 607 power density in $\mathrm{mW} \mathrm{cm}^{-3}$ is arguably more appropriate. 608 However, for this work we have chosen to remain with the 609 standard $\mathrm{mW} \mathrm{cm} \mathrm{cm}^{-2}$ convention for figures. Maximum power 610 outputs for a single EBFC in the literature are between 1.45 and 611 $2.3 \mathrm{~mW} \mathrm{~cm}^{-2}$ at 0.3 to $0.55 \mathrm{~V}^{22,23,52}$ One of these previously 612 reported biofuel cells, based on our estimates, gives up to 3.8613 $\mathrm{mW} \mathrm{cm} \mathrm{cm}^{-3}\left(1.54 \mathrm{~mW} \mathrm{~cm}^{-252}\right)$, and thus the delivery of 24.07614 $\mathrm{mW} \mathrm{cm} \mathrm{cm}^{-3}$ reported here is markedly high.

The difference in power density observed between the 616 saturated and quiescent oxygen conditions reveals that the 617 biofuel cell is strongly limited by oxygen availability at the 618 cathode. Even in the presence of oxygen-saturated conditions, 619 the biocathode is limiting.

Polarization and power curves were also recorded at freshly 621 prepared biofuel cells in the absence of glucose under oxygen- 622 saturated conditions as control experiments (Figure S13). In 623 the absence of the enzyme's substrate, the low power output 624 and a small OCV, namely $0.02 \mathrm{~mW} \mathrm{~cm}^{-2}$ and $0.53 \pm 0.02 \mathrm{~V}, 625$ clearly illustrate and confirm the unambiguous role of 626 FADGDH and the need for glucose for effective biofuel cell 627 performance.

628

In order to assess the operational stability of the biofuel cell, 629 potentiostatic and galvanostatic tests were performed for 30630 min. This duration may, for example, be considered as an 631 adequate operational time for a single use self-powered 632 biosensor. The stability of the biofuel cell was first examined 633 by applying a mild fixed voltage of $0.2 \mathrm{~V}$ and monitoring the 634 current in oxygen-saturated solution. The power obtained from 635 the recorded current revealed a stable power output of $295 \pm 636$ $25 \mu \mathrm{W} \mathrm{cm} \mathrm{cm}^{-2}$ after an initial $30 \mathrm{~s}$ induction period (Figure 6A). $637 \mathrm{f6}$ Similar glucose/oxygen biofuel cell stability has been observed 638 using FADGDH, which, notably, is vastly superior to that 639 observed with the GOx enzyme. ${ }^{14}$ The initial induction period 640 is attributed to diffusional equilibration and high charging 641 currents. To further assess the stability, a current of $500 \mu \mathrm{A}$ was 642 continuously drawn and the evolution of voltage monitored 643 (Figure 6B). Following the short initial induction period, a 644 stable voltage of $0.57 \pm 0.01 \mathrm{~V}$ is obtained.
645 



Figure 6. (A) Power generated from current discharge at $0.2 \mathrm{~V}$ and (B) voltage generated at $600 \mu \mathrm{A} \mathrm{cm}^{-2}(500 \mu \mathrm{A})$ for 30 min operation of the $\mathrm{BP}_{\mathrm{Pp}}-\mathrm{BOD} / \mathrm{BP}_{\mathrm{PLQ}}-\mathrm{FADGDH}$ biofuel cell in $\mathrm{O}_{2}$ saturated Mcllvaine buffer at $\mathrm{pH} 7.0$ with $170 \mathrm{mmol} \mathrm{L}^{-1}$ glucose. Error bars correspond to one standard deviation from three biofuel cells.

\section{CONCLUSIONS}

647 Electricity generation from glucose and oxygen using small and 648 lightweight enzymatic biofuel cells opens up the attractive 649 prospect of self-powered health and environmental sensor 650 devices. Here, we report the fabrication of new freestanding 651 redox-embedded (porphyrin, phenanthroline quinone, and 652 napthoquinone) carbon nanotube paper electrodes with 653 physical durability, practical flexibility, and excellent electro654 chemical properties. Elaboration of the electrodes for 655 construction of bioelectrodes with high catalytic performance 656 compared to literature values was subsequently demonstrated. 657 Very high catalytic performance was observed by employing 658 1,10-phenanthroline-5,6-dione as an electron transfer mediator 659 with FADGDH at the anode. The biofuel cell delivers milliwatt 660 per cubic centimeter power densities under either quiescent 661 solution (dissolved oxygen) or saturated oxygen solution 662 conditions, with $170 \mathrm{mmol} \mathrm{L}^{-1}$ glucose at neutral $\mathrm{pH}$ and 663 room temperature. In addition, the half-cell and biofuel cell 664 experiments show good operational stability, which could be 665 appropriate for disposable self-powered sensors. We expect that 666 the proposed fabrication methods, buckypapers, and use of 667 PLQ for mediated electron transfer with FADGDH will 668 advance the field of biofuel cells toward practical applications, 669 especially considering the excellent prospects of the FADGDH 670 enzyme and paper-based bioelectrodes. Future work is now 671 required to address the limiting cathode power output under 672 quiescent oxygen levels (for example, by enhancement of 673 dioxygen mass transport) and the comparatively poor stability 674 observed at the anode over several days (for example, via caging 675 and shrinking effects).

\section{ASSOCIATED CONTENT}

\section{S Supporting Information}

678 The Supporting Information is available free of charge on the 679 ACS Publications website at DOI: 10.1021/acscatal.7b00738.

680 Electrode characterization and stability, Figures S1-S13 681 (PDF)

\section{$682 \square$ AUTHOR INFORMATION}

\section{Corresponding Authors}

684 *E-mail: andrew.gross@univ-grenoble-alpes.fr. 685 *E-mail: serge.cosnier@univ-grenoble-alpes.fr.

686 ORCID

687 Andrew. J. Gross: 0000-0002-7356-7089

688 Xiaohong Chen: 0000-0002-6535-3873

689 Alan Le Goff: 0000-0002-6765-5859
Michael Holzinger: 0000-0003-3700-4673

690 Author Contributions

691

The manuscript was written through contributions of all 692 authors. All authors have given approval to the final version of 693 the manuscript.

Notes

The authors declare no competing financial interest.

\section{ACKNOWLEDGMENTS}

697

This work was supported by LabEx ARCANE (ANR-11-LABX- 698 0003-01) and ANR-15-JTIC-0002-01. The region Auvergne- 699 Rhône-Alpes is acknowledged for the Ph.D. funding of C.A. 700 The authors would also like to thank the platform Chimie 701 NanoBio ICMG FR 2607 (PCN-ICMG) and PFT "Surfaces 702 Functionalization and Transduction" for providing facilities and 703 PMIEL “Microscopy” for SEM imaging. We are very grateful to 704 Christine Lancelon Pin for assistance with SEM imaging. 705

\section{REFERENCES}

706

(1) Cosnier, S.; Gross, A. J.; Le Goff, A.; Holzinger, M. J. Power 707 Sources 2016, 325, 252-263.

(2) Slaughter, G.; Kulkarni, T. J. Biochips Tissue Chips 2015, 5 (111), 709 $1-10$.

708
709

(3) Agnès, $\mathrm{C}$, Holzinger, $\mathrm{M}, \mathrm{L}$ Le Goff, $\mathrm{A}$, Reuillard, $\mathrm{B}$, Elouarzaki, 71 K.; Tingry, S.; Cosnier, S. Energy Environ. Sci. 2014, 7, 1884-1888. 712 (4) Zebda, A.; Cosnier, S.; Alcaraz, J.-P.; Holzinger, M.; Le Goff, A.; 713 Gondran, C.; Boucher, F.; Giroud, F.; Gorgy, K.; Lamraoui, H.; 714 Cinquin, P. Sci. Rep. 2013, 3, 370-375.

715

(5) MacVittie, K.; Halámek, J.; Halámková, L.; Southcott, M.; 716 Jemison, W. D.; Lobel, R.; Katz, E. Energy Environ. Sci. 2013, 6, 81-86. 717

(6) Halámková, L.; Halámek, J.; Bocharova, V.; Szczupak, A.; Alfonta, 718

L.; Katz, E. J. Am. Chem. Soc. 2012, 134, 5040-5043. 719

(7) Cinquin, P.; Gondran, C.; Giroud, F.; Mazabrard, S.; Pellissier, 720 A.; Boucher, F.; Alcaraz, J.-P.; Gorgy, K.; Lenouvel, F.; Mathé, S.; 721 Porcu, P.; Cosnier, S. PLoS One 2010, 5, e10476. 722

(8) Jia, W.; Valdés-Ramírez, G.; Bandodkar, A. J.; Windmiller, J. R.; 723 Wang, J. Angew. Chem., Int. Ed. 2013, 52, 7233-7236.

(9) Ogawa, Y.; Kato, K.; Miyake, T.; Nagamine, K.; Ofuji, T.; 725 Yoshino, S.; Nishizawa, M. Adv. Healthcare Mater. 2015, 4, 506-510. 726

(10) Pankratov, D.; González-Arribas, E.; Blum, Z.; Shleev, S. 727 Electroanalysis 2016, 28, 1250-1266.

(11) Giroud, F.; Gross, A. J.; Faggion, D., Jr.; Holzinger, M.; Maduro 729 de Campos, C. E.; Acuña, J. J. S.; Domingos, J. B.; Cosnier, S. J. 730 Electrochem. Soc. 2017, 164, H3052-H3057.

(12) Arechederra, R. L.; Minteer, S. D. Anal. Bioanal. Chem. 2011, 732 $400,1605-1611$.

(13) Zafar, M. N.; Beden, N.; Leech, D.; Sygmund, C.; Ludwig, R.; 734 Gorton, L. Anal. Bioanal. Chem. 2012, 402, 2069-2077. 735

(14) Milton, R. D.; Giroud, F.; Thumser, A. E.; Minteer, S. D.; Slade, 736

R. C. T. Phys. Chem. Chem. Phys. 2013, 15, 19371-19379. 737

(15) Shiota, M.; Yamazaki, T.; Yoshimatsu, K.; Kojima, K.; Tsugawa, 738 W.; Ferri, S.; Sode, K. Bioelectrochemistry 2016, 112, 178-183. 739

(16) Saboe, P. O.; Conte, E.; Farell, M.; Bazan, G. C.; Kumar, M. 740 Energy Environ. Sci. 2017, 10, 14-42.

(17) Murata, K.; Akatsuka, W.; Sadakane, T.; Matsunaga, A.; 742 Tsujimura, S. Electrochim. Acta 2014, 136, 537-541.

(18) Tsujimura, S.; Murata, K.; Akatsuka, W. J. Am Chem Soc. 2014, 74 136, 14432-14437.

(19) Pinyou, P. Ruff, A, Poeller, S.; Ma S.; Ludwig R.; Schuhmann, 746 W. Chem. - Eur. J. 2016, 22, 5319-5326.

(20) Sakuta, R. Takeda, K. Ishida, T, Jgarashi, K, Samejima, Nakamura, N.; Ohno, H. Electrochem. Commun. 2015, 56, 75-78. 749 (21) Milton, R. D.; Lim, K.; Hickey, D. P.; Minteer, S. D. 750 Bioelectrochemistry 2015, 106, 56-63.

(22) Hou, C.; Lang, Q.; Liu, A. Electrochim. Acta 2016, 211, 663- 752 670. 
754 (23) Milton, R. D.; Hickey, D. P.; Abdellaoui, S.; Lim, K.; Wu, F.; 755 Tan, B.; Minteer, S. D. Chem. Sci. 2015, 6, 4867-4875.

756 (24) Ravenna, Y.; Xia, L.; Gun, J.; Mikhaylov, A. A.; Medvedev, A. G.; 757 Lev, O.; Alfonta, L. Anal. Chem. 2015, 87, 9567-9571.

758 (25) Narváez Villarrubia, C. W.; Artyushkova, K.; Garcia, S. O.; 759 Atanassov, P. J. Electrochem. Soc. 2014, 161, H3020-H3028.

760 (26) Cosnier, S.; Holzinger, M.; Le Goff, A. Front. Bioeng. Biotechnol. 7612014,2 , 2296-4185.

762 (27) Bunte, C.; Hussein, L.; Urban, G. A. J. Power Sources 2014, 247, $763579-586$.

764 (28) Narvaez Villarrubia, C. W.; Soavi, F.; Santoro, C.; Arbizzani, C.; 765 Serov, A.; Rojas-Carbonell, S.; Gupta, G.; Atanassov, P. Biosens. 766 Bioelectron. 2016, 86, 459-465.

767 (29) Bourourou, M.; Elouarzaki, K.; Holzinger, M.; Agnès, C.; Le 768 Goff, A. L.; Reverdy-Bruas, N.; Chaussy, D.; Party, M.; Maaref, A.; 769 Cosnier, S. Chem. Sci. 2014, 5, 2885-2888.

770 (30) Gross, A. J.; Robin, M. P.; Nedellec, Y.; O’Reilly, R. K.; Shan, 771 D.; Cosnier, S. Carbon 2016, 107, 542-547.

772 (31) Elouarzaki, K.; Bourourou, M.; Holzinger, M.; Le Goff, A.; 773 Marks, R. S.; Cosnier, S. Energy Environ. Sci. 2015, 8, 2069-2074.

774 (32) Reuillard, B.; Warnan, J.; Leung, J. J.; Wakerley, D. W.; Reisner, 775 E. Angew. Chem., Int. Ed. 2016, 55, 3952-3957.

776 (33) Reuillard, B.; Gentil, S.; Carrière, M.; Le Goff, A. L.; Cosnier, S. 777 Chem. Sci. 2015, 6, 5139-5143.

778 (34) Lalaoui, N.; Le Goff, A.; Holzinger, M.; Cosnier, S. Chem. - Eur. 779 J. 2015, 21 (47), 16868-16873.

780 (35) Faggion, D. F., Jr.; Haddad, R.; Giroud, F.; Holzinger, M.; 781 Maduro de Campos, C. E. M. de; Acuña, J. J. S.; Domingos, J. B.; 782 Cosnier, S. Nanoscale 2016, 8, 10433-10440.

783 (36) Kim, R. S.; Chung, T. D. Bull. Korean Chem. Soc. 2014, 35, $7843143-3155$.

785 (37) So, K.; Kitazumi, Y.; Shirai, O.; Kano, K. J. Electroanal. Chem. 786 2016, 783, 316-323.

787 (38) Lalaoui, N.; Rousselot-Pailley, P.; Robert, V.; Mekmouche, Y.; 788 Villalonga, R.; Holzinger, M.; Cosnier, S.; Tron, T.; Le Goff, A. ACS 789 Catal. 2016, 6, 1894-1900.

790 (39) Bourourou, M.; Elouarzaki, K.; Lalaoui, N.; Agnès, C.; Le Goff, 791 A.; Holzinger, M.; Maaref, A.; Cosnier, S. Chem. - Eur. J. 2013, 19, 792 9371-9375.

793 (40) Gutierrez-Sanchez, C.; Ciaccafava, A.; Blanchard, P. Y.; 794 Monsalve, K.; Giudici-Orticoni, M. T.; Lecomte, S.; Lojou, E. ACS 795 Catal. 2016, 6, 5482-5492.

796 (41) Hussein, L.; Rubenwolf, S.; von Stetten, F.; Urban, G.; Zengerle, 797 R.; Krueger, M.; Kerzenmacher, S. Biosens. Bioelectron. 2011, 26, $7984133-4138$.

799 (42) Scherbahn, V.; Putze, M. T.; Dietzel, B.; Heinlein, T.; Schneider, 800 J. J.; Lisdat, F. Biosens. Bioelectron. 2014, 61, 631-638.

801 (43) Forrow, N. J.; Sanghera, G. S.; Walters, S. J.; Watkin, J. L. 802 Biosens. Bioelectron. 2005, 20, 1617-1625.

803 (44) de Souza, J. C. P.; Iost, R. M.; Crespilho, F. N. Biosens. 804 Bioelectron. 2016, 77, 860-865.

805 (45) Cadet, M.; Gounel, S.; Stines-Chaumeil, C.; Brilland, X.; 806 Rouhana, J.; Louerat, F.; Mano, N. Biosens. Bioelectron. 2016, 83, 6080767.

808 (46) Ivnitski, D.; Branch, B.; Atanassov, P.; Apblett, C. Electrochem. 809 Commun. 2006, 8, 1204-1210.

810 (47) Reid, R. C.; Giroud, F.; Minteer, S. D.; Gale, B. K. J. Electrochem. 811 Soc. 2013, 160, H612-H619.

812 (48) Hickey, D. P.; Reid, R. C.; Milton, R. D.; Minteer, S. D. Biosens. 813 Bioelectron. 2016, 77, 26-31.

814 (49) Sakai, G.; Kojima, K.; Mori, K.; Oonishi, Y.; Sode, K. Biotechnol. 815 Lett. 2015, 37, 1091-1099.

816 (50) Meredith, M. T.; Minteer, S. D. Anal. Chem. 2011, 83, 54368175441

818 (51) Yomo, T.; Urabe, I.; Okada, H. Anal. Biochem. 1989, 179, 124819126.

820 (52) Reuillard, B.; Le Goff, A.; Agnès, C.; Holzinger, M.; Zebda, A.; 821 Gondran, C.; Elouarzaki, K.; Cosnier, S. Phys. Chem. Chem. Phys. 2013, 822 15, 4892-4896. 